\title{
Identification and diversity analysis of cassiicolin-encoding gene of Corynespora cassiicola isolates from rubber tree in Indonesia
}

\author{
FETRINA OKTAVIA \\ Indonesian Rubber Research Institute. Jl. Raya Palembang-Pangkalan Balai Km. 29, Sembawa, Banyuasin 30953, South Sumatra, Indonesia. \\ Tel.: +62-711-7439493, Fax.: +62-711-7439282, ^email: fetrina_oktavia@yahoo.com
}

Manuscript received: 4 May 2020. Revision accepted: 9 July 2020.

\begin{abstract}
Oktavia F. 2020. Identification and diversity analysis of cassiicolin encoding gene of Corynespora cassiicola isolates from rubber tree in Indonesia. Biodiversitas 21: 3499-3507. Cassiicolin is an important effector of virulence process on the Corynespora cassiicola, plant-pathogen that causes Corynespora leaf fall disease in rubber tree. The study aimed to identify and analyze the genetic diversity of isolates from rubber plants in Indonesian based on cassiicolin encoding gene (Cas gene). Identification of Cas genes was performed using 12 pairs of primers on 23 isolates from rubber host clones. Only three pairs of primers were able to amplify the analyzed DNA, namely CasF20/CasR28, CasF19/CasR26, and CasF4/R16 which produced DNA fragments of $760 \mathrm{bp}, 550 \mathrm{bp}$ and 210 bp respectively in this study. BLAST analysis showed that 19 isolates carried a Cas 5 gene. Three of the 19 DNA samples also contained a putative Cas 3 or Cas4 gene. Four other isolates had no detectable Cas gene (Cas0). The genetic diversity based on the Cas gene showed that the isolates were grouped into three major clusters. Some isolates had high genetic similarity with outgroup isolates from China. There was not clear link between Cas gene with virulence profiles. The cassiicolin encoding gene information is useful for predicting the virulence of $C$. cassiicola isolates from Indonesia rubber plantation, so that the disease severity spreading in rubber plants can be early anticipated.
\end{abstract}

Keywords: Cas gene, Corynespora leaf fall disease, Hevea brasiliensis, pathogen effector, toxin

\section{INTRODUCTION}

Corynespora cassiicola (Berk. \& M. A. Curtis) is a plant-pathogen fungus related to more than 400 hosts (Farr and Rossman, 2019), causing symptoms on leaves, stems, roots, flowers and fruit (Dixon et al. 2009). In rubber plants, it causes the Corynespora leaf fall (CLF) disease which attacks all stages of growth and development of rubber plants both on immature and mature leaves, leading to massive defoliation and growth retardation, latex production decline and in severe circumstances cause death of plant (Othman 2013; Fernando et al. 2010; Ogbebor 2010).

The symptom of CLF disease on rubber plants is characterized by necrotic lesions of the leaves with a "fishbone" pattern. The necrotic lesions are caused by the secretion of phytotoxic compounds (Friesen et al. 2008; Petrov et al. 2018) called cassiicolin (Breton et al. 2000). Cassiicolin toxicity is host-specific (Barthe et al. 2007) and clone dependent (Deon et al. 2012a), which propose that there are interactions between cassiicolin with specific plant sensitivity factors. Characterization of the factors that influence the pathogenicity of $C$. cassiicola that cause CLFD showed that cassiicolin is a major effector that plays an important role in the process of $C$. cassiicola infection in rubber plants (de Lamotte et al. 2007; Breton et al. 2000; Déon et al. 2012a,b; Lopez et al. 2018; Ribeiro et al. 2019). This protein plays an important role in the early stages of infection in plants, where peak of production was found before the initial symptoms on 1-2 days after infection, both in susceptible and resistant clones (Déon et al. 2012a). The transcription of the gene is up-regulated during the early phase of the compatible interaction with the rubber tree (Lopez et al. 2018). Cassiicolin is a cysteine-riched glycosylated Small Secreted Protein (SSP) that have molecular mass 2885 Da. Characterization on 3 of $C$. cassiicola isolates with different virulence levels showed that cassiicolin successfully purified from the isolate with high and medium virulent (CCP and CCAM3 respectively) but not from the isolate with low virulent (CCAM1) (Déon et al. 2012a).

Déon et al. (2014) identified six cassiicolin class (Cas1 to Cas6), through PCR amplification and sequencing of Cas genes, among C. cassiicola isolates from different hosts and regions. Cas 2 and Cas 6 were occasionally found in the same isolate. The isolates which no detect Cas gene was grouped into the so-called Cas 0 class. Furthermore, Lopez et al. (2018) reported a new cassiicolin gene named Cas7, with only $72.3-76.7 \%$ nucleotide sequence identity and $71.9-77.8 \%$ deduced amino acid sequence identity, compared to the previous cassiicolin genes. Some Cas 0 isolates (without cassiicolin gene) are nevertheless virulent on the rubber tree, suggesting that there are other effectors besides the Cas gene in the process of C. cassiicola infection (Pujade-Renaud et al. 2015). Isolates that have Cas 1 class were found the most aggressive on the range of clones tested (Déon et al. 2014)

Cassiicolin is considered to be a major determinant of the pathogenicity of $C$. cassiicola. This is supported by the fact that sensitivity to the toxin is in line with susceptibility to the toxin-producing isolate, and conversely, resistance to the toxin is in line with resistance to the fungus (Breton et al. 2000; Déon et al. 2012a). Two QTL associated with the 
sensitivity to cassiicolin Cas1 were identified (Tran et al. 2016; Ribeiro et al 2019).

Identification and characterization of the cassiicolin encoding genes of $C$. cassiicola isolate collected from various countries have been reported, including Brazil (Deon et al. 2012b), Philippines, Sri Lanka (Deon et al. 2014), Malaysia (Shuib et al. 2015) and China (Liu et al. 2016; Wu et al. 2018). As the country with the largest rubber plantation area (about 3.67 million ha) with various different geographical conditions, Indonesia has a large genetic diversity of $C$. cassiicola isolates. The diversity may indicate the influence of environmental factors on the development and pathogenicity of $C$. cassiicola isolates. The difference in pathogenicity could be related to the type of cassiicolin-encoding gene. The diversity of these cassiicolin-encoding genes and their relationship with isolates virulence on rubber plants in Indonesia has not been reported. The information will greatly assist disease control strategies such as identification of sources of resistance genes, predictions of genetic drift as well as development and spread of resistant varieties (Rampersad et al. 2013). The purpose of the research was to identify the genetic diversity of the cassiicolin-encoding genes in $C$. cassiicola isolates that caused Corynespora leaf fall disease in rubber plants from Indonesia.

\section{MATERIALS AND METHODS}

\section{Material of Corynespora cassiicola isolates}

Cassiicolin-encoding gene identification was carried out on 23 C. cassiicola isolates collected from the GT 1 clone from six different rubber plantation locations in Indonesia and from 17 other rubber clones in the Experimental Garden of Indonesian Rubber Research Institute in South Sumatra on 2013. The isolates were isolated from rubber leaves showing symptoms of CLF disease using PDA medium contained chloramphenicol $0.05 \%$. Single spore purification was conducted from 10 days old cultures as described previously (Oktavia et al. 2017). Spores were collected in water and spread onto water-agar plates. The single spores were identified under microscope (their position was marked) and sub-cultured onto new PDA medium. Identification of the isolates using the ITS-rDNA gene and their virulence against six rubber clones was reported by Oktavia et al. (2017). Table 1 shows the list of C. cassiicola isolates analyzed, information of host clone, and geographic origin of isolates.

\section{DNA extraction}

DNA extraction was carried out using mycelia samples of each isolate. Propagation of mycelia was carried out in $100 \mathrm{ml}$ Potato Dextrose Broth on Erlenmeyer flasks that shaken at $60 \mathrm{rpm}$ using orbital shaker for 10 days. The mycelia were collected, rinsed with sterile water, and used for DNA extraction (Nghia et al. 2010). The purity and concentration of DNA were measured using a spectrophotometer on $260 \mathrm{~nm}$. Furthermore, DNA is stored at $4{ }^{\circ} \mathrm{C}$ and ready to be used as a stock for DNA templates in PCR amplification.
Table 1. Host clone and geographical origin of Corynespora cassiicola isolates used for Cas gene detection

\begin{tabular}{|c|c|c|}
\hline CC isolates* & Host clone & Geographic origin ** \\
\hline$\overline{\mathrm{CC}-01}$ & GT 1 & North Sumatra \\
\hline CC-02 & GT 1 & Bengkulu \\
\hline CC-03 & GT 1 & Jambi \\
\hline CC-04 & GT 1 & Central Java \\
\hline CC-05 & GT 1 & East Kalimantan \\
\hline CC-06 & GT 1 & South Sumatra \\
\hline CC-07 & IRR 32 & South Sumatra \\
\hline CC-08 & IRR 72 & South Sumatra \\
\hline CC-09 & IRR 104 & South Sumatra \\
\hline $\mathrm{CC}-10$ & IRR 105 & South Sumatra \\
\hline $\mathrm{CC}-11$ & IRR 107 & South Sumatra \\
\hline $\mathrm{CC}-12$ & IRR 112 & South Sumatra \\
\hline CC-13 & IRR 118 & South Sumatra \\
\hline CC-14 & LCB 1320 & South Sumatra \\
\hline $\mathrm{CC}-15$ & PB 217 & South Sumatra \\
\hline $\mathrm{CC}-16$ & PB 260 & South Sumatra \\
\hline $\mathrm{CC}-17$ & PB 330 & South Sumatra \\
\hline CC-18 & PR 261 & South Sumatra \\
\hline CC-19 & PR 300 & South Sumatra \\
\hline $\mathrm{CC}-20$ & PR 303 & South Sumatra \\
\hline $\mathrm{CC}-21$ & RRIC 100 & South Sumatra \\
\hline $\mathrm{CC}-22$ & RRIM 600 & South Sumatra \\
\hline $\mathrm{CC}-23$ & TJIR 1 & South Sumatra \\
\hline
\end{tabular}
were collected indicated by name of Province

\section{Identification and characterization of cassiicolin- encoding gene (Cas gene)}

Identification of Cas gene was carried out using two specific primer groups. The first group was 5 pairs of primers targeting the class-specific of Cas sequences and 1 primer targeting the full length of Cas gene based on reported references in Table 2 . The second primer group is 6 pairs of primers which are designed based on the detection of specific DNA sequences of each isoform by aligning Cas gene sequence from the NCBI (National Centre for Biotechnology Information) database. Based on the specificity of each sequence the primer design was carried out using the Primer3plus program which produces 6 forward and 1 reverse primer which would be paired for all forward primers. The primers were synthesized at Integrated DNA Technologies (IDT) Singapore. Table 2 shows the list of primers used.

PCR amplification was carried out using DNA thermal cycler (T-Personal, Biometra, Germany). The PCR reaction consisted of 1x PCR buffer, $0.2 \mathrm{mM}$ dNTP mix, $2 \mathrm{mM}$ $\mathrm{MgCl} 2$, 0.5 U Taq polymerase (Kapa Biosystem Inc. USA), $0.2 \mu \mathrm{M}$ for each forward and reverse primers, $5 \mathrm{ng}$ DNA templates, final volume to $25 \mu \mathrm{l}$. The PCR program was set based on the Taq polymerase reference manual used. Initial denaturation was done at $95{ }^{\circ} \mathrm{C}$ for $3 \mathrm{~min}$, followed by denaturation $95{ }^{\circ} \mathrm{C}$ for $15 \mathrm{sec}$, annealing 54-58 ${ }^{\circ} \mathrm{C}$ (depend on temperature of primary annealing used) for $15 \mathrm{sec}$, extension $72^{\circ} \mathrm{C}$ for $30 \mathrm{sec}$ as much as 35 cycles and final extension at $72{ }^{\circ} \mathrm{C}$ for $3 \mathrm{~min}$. PCR reactions were carried out in three technical replications. The 
amplification results were confirmed through $1 \%$ agarose gel electrophoresis containing gelled using 1xTBE buffer at $60 \mathrm{~V}$ for $60 \mathrm{~min}$. Furthermore, the gel was observed under UV and documented. The size of DNA fragment from PCR was estimated using a $1 \mathrm{~kb}$ DNA ladder (Geneid).

The PCR products were sequenced by a commercial sequencing service (First BASE Laboratories Sdn. Bhd. Malaysia) using each primer pair. Sequencing was done based on Sanger's dideoxy sequencing technology with BigDye Terminator v3.1 chemistry (Applied BioSystems) cycle sequencing kit. The sequencing data were edited by using BioEdit program version 7.2 (Hall 1999). Sequences produced by reverse primers were transformed into reverse complement and then alignments were made with sequences produced from primer forwards to see ambiguous nucleotides on the chromatogram.

The Cas genes identity of sequences was confirmed by homology analysis these sequences using BLAST alignment of Cas gene in GeneBank (NCBI). Analysis of Indonesian isolates clustering was performed based on the Cas and ITS-rDNA gene sequences (Oktavia et al. 2017). To detect the similarity the Cas sequences of isolates with other isolates in Gene Bank database as outgroup, all sequences were aligned and phylogenetic analysis was performed using the Neighbor-Joining (NJ) method with number of bootstrap of 1000 by Geneious Pro Trial software (version 5.6.6) (Drummond et al. 2012). A list of accession numbers of Cas gene sequences used as an outgroup (isolates from outside Indonesia) was shown in Table 3.

Table 3. List of accession number of Cas gene sequence, species of host, origin of country of Corynespora cassiicola isolate and Cas class used as outgroup

\begin{tabular}{llll}
\hline Acc. no. & Host species & $\begin{array}{l}\text { Origin of } \\
\text { country }\end{array}$ & $\begin{array}{l}\text { Cas } \\
\text { class }\end{array}$ \\
\hline KY784912 & H. brasiliensis & China & Cas5 \\
KY784913 & H. brasiliensis & China & Cas5 \\
EF667973 & H. brasiliensis & Philippines & Cas 1 \\
JF915148 & H. brasiliensis & Philippines & Cas1 \\
JF915155 & H. brasiliensis & Brazil & Cas2 \\
MF464454 & H. brasiliensis & China & Cas5 \\
JF915170 & H. brasiliensis & Brazil & Cas3 \\
JF915169 & H. brasiliensis & Brazil & Cas3 \\
JF915183 & H. brasiliensis & Brazil & Cas6 \\
JF915180 & H. brasiliensis & Sri Lanka & Cas5 \\
JF915168 & H. brasiliensis & Brazil & Cas2 \\
JF915171 & H. brasiliensis & Brazil & Cas4 \\
KM873318 & H. brasiliensis & Malaysia & Cas4 \\
JF915167 & L. camara & Brazil & Cas2 \\
JF915182 & G. hirsutum & Brazil & Cas6 \\
JF915181 & G. max & Brazil & Cas6 \\
\hline
\end{tabular}

Table 2. Cas gene primers, primer sequences, annealing temperature (TA) of PCR, class target and primers of reference used in the research

\begin{tabular}{|c|c|c|c|c|c|}
\hline Primer & Sequence of primers $\left(5^{\prime}-3^{\prime}\right)$ & Target gene & $\begin{array}{c}\text { TA } \\
\left({ }^{\circ} \mathbf{C}\right)\end{array}$ & $\begin{array}{c}\text { Expected } \\
\text { lenght of } \\
\text { amplicons (bp) }\end{array}$ & Reference \\
\hline CasF9/R16 & $\begin{array}{l}\text { F: ATCAATTCCAAATCTTGAAAATCTGTCC } \\
\text { R: GGATCCGTAAGAGTATAAATTTGTGTATG }\end{array}$ & Cas 1 & 54 & 574 & Deon et al. 2012a \\
\hline CasF18/CasR27 & $\begin{array}{l}\text { F: CCCAAGATACATGTTTTGAATGT } \\
\text { R: CCACACAAAGCAAGATACAGAATGAGC }\end{array}$ & Cas 1 & 56 & 574 & Deon et al. 2014 \\
\hline CasF17/CasR24 & $\begin{array}{l}\text { F: GGATTTGCCTGAGATCCTA } \\
\text { R: CAAACAATGCTAACCAAACAAAC }\end{array}$ & Cas 2 & 58 & 578 & Deon et al. 2014 \\
\hline casF20/CasR28 & $\begin{array}{l}\text { F: GTCGGCTAACTTGGGAAAAACTCT } \\
\text { R: GCAGGAAGCAAAACACAGAACAAG }\end{array}$ & $\begin{array}{l}\text { Cas } 3, \\
\text { Cas } 4\end{array}$ & 55.5 & 574 & Deon et al. 2014 \\
\hline CasF19/CasR26 & $\begin{array}{l}\text { F: CGGGGAGGTATCAGGTGTGAGATA } \\
\text { R: CAGAACAAGCCAAAAGAGAACTAC }\end{array}$ & Cas 5 & 55 & 575 & Deon et al. 2014 \\
\hline CasF16/CasR25 & $\begin{array}{l}\text { F: GCTTGATTTGCCTGTGAGATACT } \\
\text { R: AAAACGATGCTAAACAAAAGGA }\end{array}$ & Cas6 & 55 & 582 & Deon et al. 2014 \\
\hline CasF1/R16 & $\begin{array}{l}\text { F: GACTTGCGTACGTCTTGACTCAC } \\
\text { R: GGATCCGTAAGAGTATAAATTTGTGTATG }\end{array}$ & Cas 1 & 57 & 536 & Design primer \\
\hline CasF2/R16 & $\begin{array}{l}\text { F: ATGCACTATCAGTTCGAAATCTTTGAG } \\
\text { R: GGATCCGTAAGAGTATAAATTTGTGTATG }\end{array}$ & Cas 2 & 56 & 426 & Design primer \\
\hline CasF3/R16 & $\begin{array}{l}\text { F: CGGCTTTCGTAGCAGCCA } \\
\text { R: GGATCCGTAAGAGTATAAATTTGTGTATG }\end{array}$ & Cas3 & 58 & 250 & Design primer \\
\hline CasF4/R16 & $\begin{array}{l}\text { F: GTGTTCGGGCTGTTAGCTTAAGTAGT } \\
\text { R: GGATCCGTAAGAGTATAAATTTGTGTATG }\end{array}$ & Cas 4 & 57 & 240 & Design primer \\
\hline CasF5/R16 & $\begin{array}{l}\text { F: CTTTTAAACCTGTCCCATACATTTGCTAT } \\
\text { R: GGATCCGTAAGAGTATAAATTTGTGTATG }\end{array}$ & Cas5 & 55 & 380 & Design primer \\
\hline CasF6/R16 & $\begin{array}{l}\text { F: GCTTCTTAAGTACCATCAATTCCAAT } \\
\text { R: GGATCCGTAAGAGTATAAATTTGTGTATG }\end{array}$ & Cas6 & 56 & 400 & Design primer \\
\hline
\end{tabular}




\section{RESULTS AND DISCUSSION}

\section{Identification and characterization of $\mathrm{Cas}$ gene}

Among the 12 pairs of primers used for PCR amplification on the 23 isolates, only CasF20/CasR28, CasF19/CasR26 and CasF4/R16 produced a DNA fragment, while the other primers failed to amplify any target. The primers CasF20/CasR28, expected to target Cas3 and Cas4 genes produced a 760 bp DNA fragment from 19 isolates. Four isolates (CC-10, CC-15, CC-18, CC21) showed no amplification (Figure 1).

PCR amplification by CasF19/CasR26 primer pair which was aimed to amplify the Cas5 gene was only successful in 7 isolates of $C$. cassiicola, which is $\mathrm{CC}-01$, CC-04, CC-05, CC-08, CC-11, CC-12, and CC-13 isolates, while 17 other isolates did not provide amplification results. The DNA fragment produced by the CasF19/CasR26 primer was 550 bp in size (Figure 2). The results showed that 7 isolates namely $\mathrm{CC}-01, \mathrm{CC}-04, \mathrm{CC}-$ 05, CC-08, CC-11, CC-12, and CC-13 produced amplification of DNA fragments with both CasF20/CasR28 and CasF19/CasR26 primer pairs.

CasF4/R16 primers pair, designed based on the specific sequence of Cas 4 isoform, amplified a 210 bp DNA fragment in three isolates (CC-07, CC-22, CC-23) while for 20 other isolates there was no amplification (Figure 3 ).

Out of 23 tested isolates, four isolates have no amplification, whatever the primers pair used. This suggests that the primers may have failed to detect the Cas gene present in these isolates or that the isolates do not carry the Cas gene. Shuib et al. (2015) reported the identification of the Cas gene of $C$. cassiicola to isolate from rubber plantation in Malaysia, which PCR amplification was only successful in 13 of 26 isolates analyzed and the other 13 were considered to have no Cas gene. Isolates without detectable Cas gene were classified as Cas0 (Déon et al. 2014), and some of these isolates were virulent, so it has been predicted that effectors other than cassiicolin were involved in their virulence (Déon et al 2014).

The results of the BLAST analysis showed that the 19 sequences obtained with CasF20/CasR28 primers designed to amplify Cas 3 or Cas 4 genes were in fact highly homologous to Cas5. The Sequences have the highest similarity of $99.68 \%$ with an accession number of KY784913 which is a Cas5 gene from a $C$. cassiicola isolate from China. BLAST analysis of the seven sequences resulting from CasF19/CasR26 amplification showed that the sequences belong to the Cas 5 isoform with the highest similarity with MF464454 of $97.85 \%$. Whereas sequences amplified with the CasF4/R16 primers, purposed to amplify Cas4, had the highest similarity with a Cas3 gene of accession number JF915170 (96.77\% identity). Nevertheless, these sequences also have $96.26 \%$ identity with the Cas4 gene JF915171.

These results showed that there is a difference between the Cas gene expected to be targeted by the primers and the results of BLAST analysis in three primers amplified both on primers from references (CasF20/CasR28) and primer designed specifically for the Cas 4 isoform sequence (CasF4/R16). It was expected due to there were only a few of differences of nucleotide bases between Cas3, Cas4, and Cas 5 isoforms, which caused there was a possibility the primers amplify the different isoform. Figure 4 shows the multiple alignments of example differences of nucleotide of Cas3, Cas4, and Cas5 gene sequences of accessions numbers JF915170, JF915171, and MF464454 from NCBI. When their mature cassiicolin domain where compared, it would appear $100 \%$ identical to each other (Deon et al. 2014).

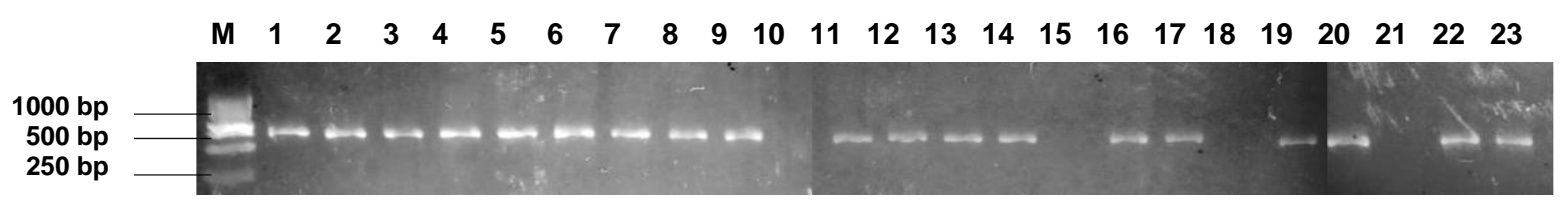

Figure 1. DNA fragments resulting of PCR amplification with CasF20/CasR28 primer (target of Cas3 or 4 genes). M = $1 \mathrm{~kb}$ of DNA marker; $1,2, \ldots 23=$ CC-01, CC- $02, \ldots$ CC- 23

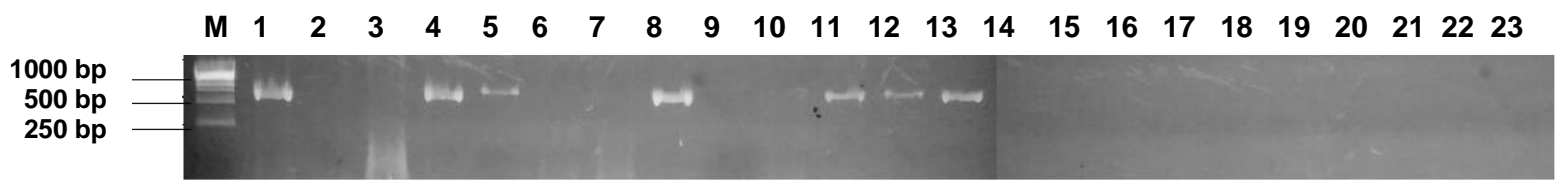

Figure 2. DNA fragments resulting of PCR amplification with CasF19/CasR26 primer (Target of Cas5 isoform). M = $1 \mathrm{~kb}$ of DNA marker; $1,2, \ldots 23=$ CC-01, CC-02,...CC-23

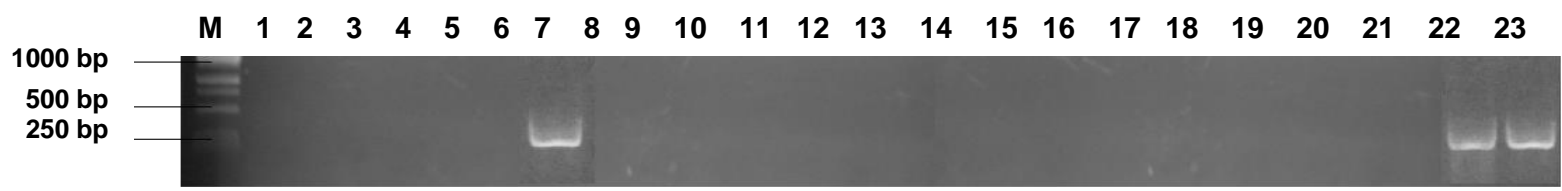

Figure 3. DNA fragments resulting of PCR amplification with CasF4/R16 primer (Target of Cas 4 isoform). $\mathrm{M}=1 \mathrm{~kb}$ of DNA marker; $1,2, \ldots .23=\mathrm{CC}-01, \mathrm{CC}-02, \ldots \mathrm{CC}-23$ 


\section{Analysis of genetic diversity of Corynespora cassiicola isolate}

Phylogenetic analysis of $C$. cassiicola isolates based on sequences of Cas gene and ITS-rDNA gene that reported on previous study (Oktavia et al. 2017) using the NeighborJoining method showed high diversity (Figure 5). The isolates grouped into three clusters. Most isolates belong to the first cluster, three isolates (CC-10, CC-15, and CC-18) belong to the second cluster and only one isolate (CC-21) belongs to the third cluster. The isolates with Cas5 and Cas $5+$ Cas 3 gene join to cluster one, whereas isolates that have the Cas 0 gene grouped into second and third clusters. Similar clustering was found in Malaysian $C$. cassiicola isolates, which cluster 1 with all Cas5 and cluster 2 of Cas 0 , cluster 2, and 3 are Cas 4 and Cas 0 . Using more genes, Deon et al (2014) found eight major clades among 70 isolates and $47 \%$ of these isolates carried at least one cassicolin gene.

The clustering of isolates did not show clear correlation with the host clone and geographical origin of isolates. Even though six isolates were collected from the same clone (GT 1) in different locations are in the same big group, but they divided into different small groups. Nevertheless, CC-02, CC-03, and CC-06 isolate that collected from Bengkulu, Jambi and South Sumatra have a close relationship. In fact, the three locations indicated by the name of the province are in a contiguous location on the Sumatra island, Indonesia. Likewise with CC-04 and CC-05 isolates that come from Central Java and West Kalimantan were in the same small group. Different from these 5 isolates, CC-01 from North Sumatra was quite away apart in the other small groups. The grouping of these isolates was different from previous study using ITS-rDNA sequences (Oktavia et al. 2017). This could occur because addition of Cas gene sequences which have a high nucleotides variation than ITS-rDNA sequences that just have 3 of different nucleotide, so that this grouping was expected to be more slightly accurate to find out the genetic diversity of isolates. Deon et al. (2014) reported that the cassiicolin genes have significantly contributed to the structuration of $C$. cassiicola which suggesting important role of the genes in biology and evolution of fungus. Besides both of the genes, caa5, ga4, and act 1 are other genes used to explore genetic diversity of $C$. cassiicola isolates (Dixon et al. 2009; Deon et al. 2014; Shuib et al. 2015; Banguela-Castillo et al. 2020).

Figure 6 showed the large genetic diversity of $C$. cassiicola isolates from various species in some countries based on the cassiicolin gene from various classes. Phylogenetic analysis showed that based on the cassiicolin gene, $C$. cassiicola isolates were separated into two major clusters, which most of the Indonesian isolates belong to the first cluster. The first major cluster was a mixture of isolates from Indonesia and other countries. This cluster is divided into two subclusters IA and IB. Indonesian isolates belonging to subgroup IA have a genetic closeness with outgroup isolates in subgroup IB consists of accession number JF915180, MF464454, KY784912 and KY784913. All of these isolates had the Cas 5 gene which originated from host of rubber plants in China except isolate accession number JF915180 from Sri Lanka (Table 3).

The second major cluster was all Indonesian and outgroup isolates respectively. The last cluster which comes from different host and country separated into two subclusters named IIIA and IIIB. Isolates with other accession numbers that have Cas1, 2, and 6 genes originating from various hosts and countries clustered into small groups according to Cas class, and all of them are incorporated into the IIIA subcluster. One of Indonesian isolate, CC-18 was incorporated into small group in this subcluster. Subcluster IIIB consist of isolate carried Cas3 and Cas 4 genes (Table 3). The closeness of the clustering could occur because of the high of nucleotide similarity between Cas3 and Cas4 sequences (Figure 4).

\section{Correlation of Cas gene with virulence level of Corynespora cassiicola isolates}

Table 4 shows the list of Cas gene class, virulence level, and phylogenetic clade based on the virulence of isolates analyzed. Based on the results of BLAST analysis it was known that 19 of $C$. cassiicola isolates have the Cas 5 and three of them also carry the Cas 3 (CC-07, CC-22 and $\mathrm{CC}-23)$. These isolates were joined into the same phylogenetic clade except CC-07 isolate. One isolate had more than one Cas gene class was reported in another study. Xianbao et al. (2016) reported that Cas5 and Cas2 were found on $C$. cassiicola isolates from rubber plant hosts in China. The development of molecular barcoding to detect Cas gene showed that Cas5 in China reached $94.8 \%$ of the tested isolates (Boxun et al. 2019) and there are associated between the pathogenicity and host specificity of Cas5 isoform of cassiicolin gene that reveals the roles of Cas 5 toxin protein in the pathogenicity of $C$. cassiicola (Xianbao et al. 2019). In some cases, an isolate can have more than one type of isoform at a time such as Cas 2 was found together with Cas6 in same isolates from Glycine $\max ($ Deon et al. 2014) and Cas 2 with $\operatorname{Cas} 7$ on isolates from $H$. brasiliensis (Lopez et al. 2018). Furthermore, we found an absence of Cas gene in 4 isolates analyzed that conjugate in clade II. All these isolates had a weak virulence. 16 of isolates had Cas5 gene had varying levels of virulence, ranging from weak to extreme virulence. According to Déon et al. (2014) it could occur due to the influence of other effectors.

Previous studies have analyzed the relationship between the type of Cas gene carried and the virulence ability of $C$. cassiicola isolates. Cas 1 is found in isolates that have a high virulence level (Déon et al. 2014), and the gene is expressed in the early stages of $C$. cassiicola infection in rubber plants (Deon et al. 20112a; 2012b). It is a major effector on the process of isolate virulence and filtrate toxicity (Tran et al. 2016; Ribeiro et al 2019). Cas4 was found in isolates that had moderate virulence, whereas Cas 2, 3, 5, and 6 were isoforms that were found on isolates classified as weak virulence. These results were obtained on a specific range of clones. 


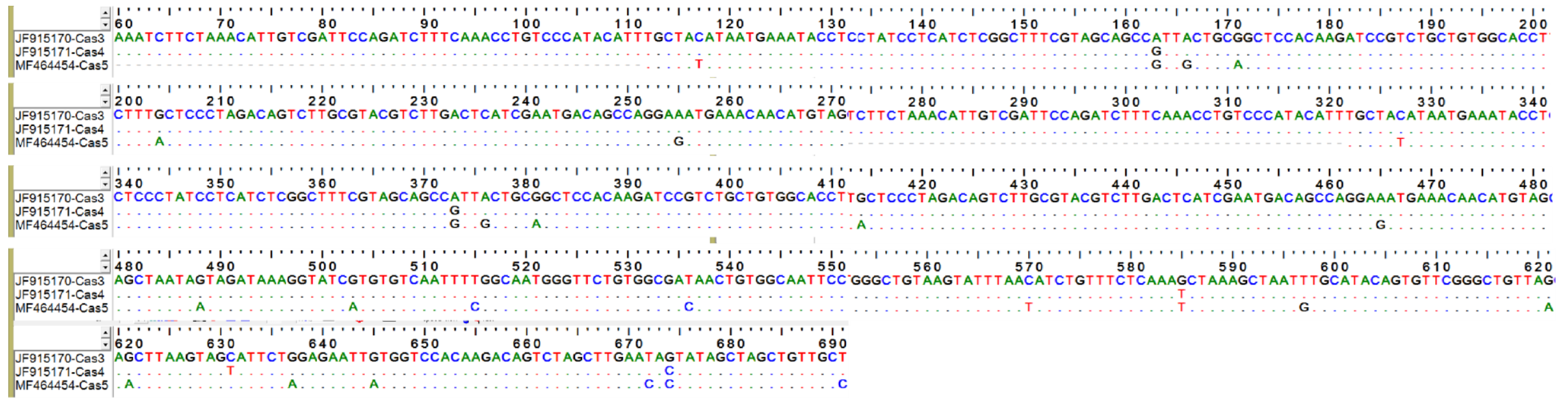

Figure 4. Multiple alignments of Cas3, Cas4 and Cas5 nucleotide sequences from three Corynespora cassiicola isolates (Gene Bank of NCBI) 


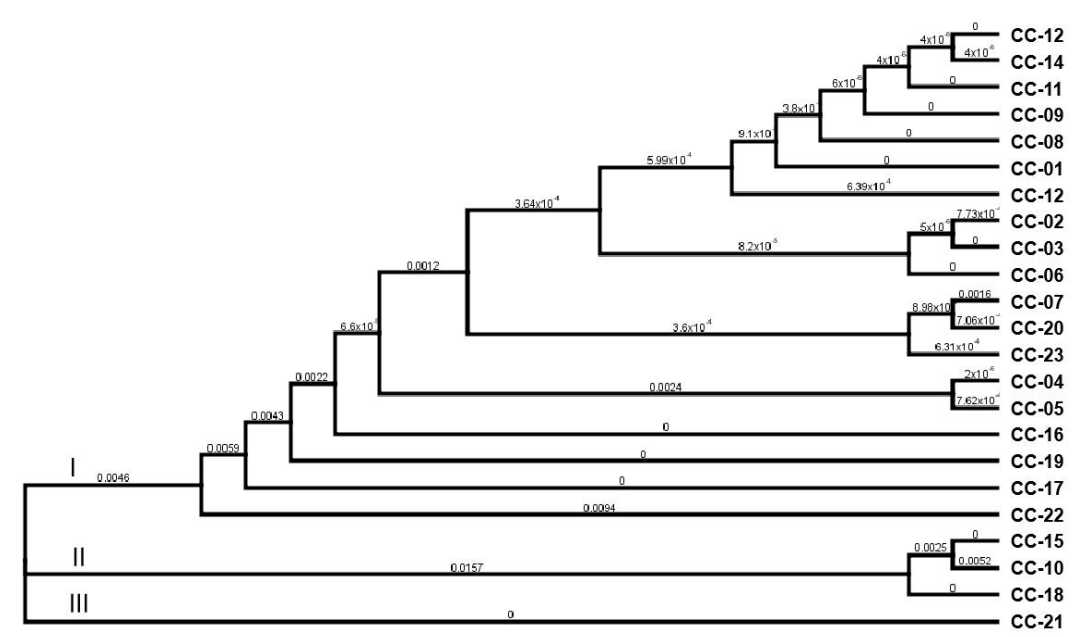

Figure 5. Phylogenetic trees 23 Corynespora cassiicola isolates from rubber plant in Indonesian based on Cas and ITS-rDNA gene sequences using Neighbor-Joining (NJ) method

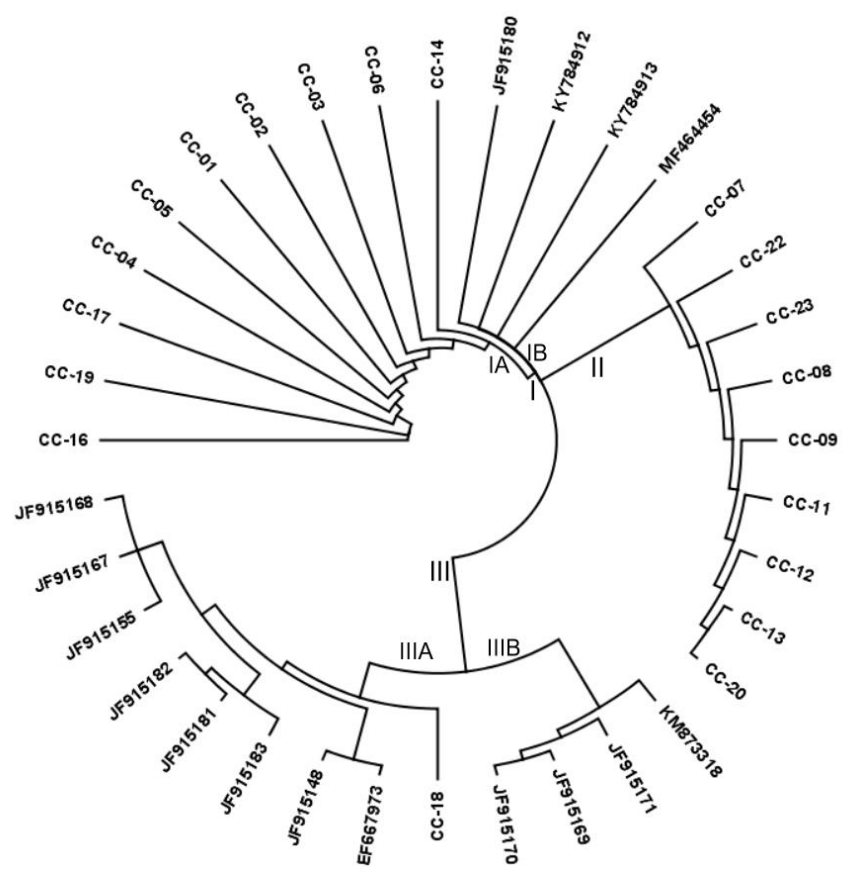

Figure 6. Phylogenetic trees 19 Corynespora cassiicola isolates from rubber plant in Indonesian and 15 isolates from other countries taken from database sequences (accession numbers) based on Cas gene sequences using the Neighbour-Joining (NJ) method

If just based on these information we would expect $C$. cassiicola isolates from Indonesian rubber plantation to be weakly virulent since they carry $\operatorname{Cas} 3$ and $C a s 5$, but based on previous study (Oktavia et al. 2017) these isolates had a high virulence on specific clones. The same case was reported by Shuib et al. (2015) that found the Cas5 in $C$. cassiicola isolates from Malaysian rubber plantation in which had a high virulence. If we review severity of attack of Corynespora leaf fall disease in rubber plantations in Indonesia and Malaysia around 1982-2020, so that it showed the high of $C$. cassiicola isolate virulence in both countries. The difference of the results could occurred due to the Cas 1 gene was not detected in the PCR conditions conducted in this study, the differences of rubber clones used in the test, or the existence of other yet unknown effectors of virulence. Based on genome-wide analysis conducted by Lopez et al. (2018) it was known that there are 2870 putative effectors involved in C. cassiicola infections in rubber plants, and 92 of these effectors have a large role in the infection process. These effectors include CAZymes, lipases, peptidases, secreted proteins, and enzymes associated with secondary metabolites. Ribeiro et al. (2019) confirmed that Cas 1 is a necrotrophic effector conferring virulence to susceptible rubber clones in the early infection. Other effectors contribute to residual filtrate toxicity and virulence in senescing of wounded tissues. These other effectors may be involved in saprotrophy rather than necrotrophy. 
Table 4. List of Corynespora cassiicola isolate, Cas class, the levels of filtrate toxicity on rubber plants and phylogenetic clade

\begin{tabular}{cclc}
\hline CC isolates & Cas gene & $\begin{array}{c}\text { Isolate virulence } \\
\text { level }^{* * *}\end{array}$ & $\begin{array}{c}\text { Phylogenetic } \\
\text { clade*** }^{*}\end{array}$ \\
\hline CC-01 & Cas5 & Strong virulence & I \\
CC-02 & Cas5 & Strong virulence & I \\
CC-03 & Cas5 & Strong virulence & I \\
CC-04 & Cas5 & Strong virulence & I \\
CC-05 & Cas5 & Strong virulence & I \\
CC-06 & Cas5 & Strong virulence & I \\
CC-07 & Cas3, Cas5 & Strong virulence & I \\
CC-08 & Cas5 & Weak virulence & II \\
CC-09 & Cas5 & Strong virulence & II \\
CC-10 & Cas0 & Weak virulence & II \\
CC-11 & Cas5 & Weak virulence & II \\
CC-12 & Cas5 & Strong virulence & II \\
CC-13 & Cas5 & Weak virulence & II \\
CC-14 & Cas5 & Strong virulence & II \\
CC-15 & Cas0 & Weak virulence & II \\
CC-16 & Cas5 & Strong virulence & I \\
CC-17 & Cas5 & Weak virulence & II \\
CC-18 & Cas0 & Weak virulence & II \\
CC-19 & Cas5 & Strong virulence & II \\
CC-20 & Cas5 & Extreme virulence & III \\
CC-21 & Cas0 & Weak virulence & II \\
CC-22 & Cas3, Cas5 & Extreme virulence & III \\
CC-23 & Cas3 Cas5 & Extreme virulence & III \\
\hline
\end{tabular}

Note: $* \mathrm{CC}=$ C. cassiicola $^{* *}{ }^{* *}$ and ${ }^{* * *}$ Based on the virulence test of each C. cassiicola isolate to six rubber clones (RRIC 100, BPM 24, BPM 1, PB 260, GT 1 and RRIM 600) that have different levels of resistance to CLFD (Oktavia et al. 2017)

To conclude, cassiicolin-encoding genes were successfully identified in $C$. cassiicola isolates from Indonesian rubber plantation. These genes encoded either Cas 5 and Cas 3 class. Phylogenetic analysis based on Cas genes showed these isolates have a high similarity with $C$. cassiicola isolates from China carrying the Cas 5 gene. Although all these isolates showed various levels of filtrate toxicity on different clones, it is still difficult to link the cassiicolin gene class with virulence profiles. The information is useful for predicting the virulence of $C$. cassiicola isolates from Indonesia rubber plantation, so that the danger of the development of disease severity in rubber plants can be early anticipated.

\section{ACKNOWLEDGEMENTS}

The authors would like to acknowledge Dr. Thomas Wijaya and Andi Nur Cahyo for his revision of the English and thankful for the financial support of Indonesian Rubber Research Institute for this research.

\section{REFERENCES}

Banguela-Castillo A, Pedro L, Ramos-González, Peña-Marey M, Claudia V, Godoy, Harakava R. 2020. An updated phylogenetic classification of Corynespora cassiicola isolates and a practical approach to their identification based on the nucleotide polymorphisms at the ga4 and $\begin{array}{lllll}\text { caa5 loci. Mycologia } 112 & \text { (1): 24-38. DOI: }\end{array}$ 10.1080/00275514.2019.1670018

Barthe P, Pujade-Renaud V, Breton F, Gargani D, Thai R, Roumestand C, et al. 2007. Structural analysis of cassiicolin, a host-selective protein toxin from Corynespora cassiicola. J Mol Biol 367 (1): 89-101. DOI: 10.1016/j.jmb.2006.11.086 PMID: 17234212

Boxun L, Xianbao L, Yanli F, Huiting X, Guixiu H. 2019. Construction of Cassiicolin Genes Barcode Database and Molecular Detection Technology of Corynespora cassiicola from Hevea brasiliensis in China. Chinese J Tropical Crops 40 (9): 1770-1782.

Breton F, Sanier C, d'Auzac A. 2000. Role of cassiicolin a host-selective toxin in pathogenicity of Corynespora cassiicola, causal agent of a leaf fall disease of Hevea. J Rubb Res 3 (2): 115-128.

de Lamotte F, Duviau MP, Sanier C, Thai R, Poncet J, Bieysse D, Breton F, Pujade-Renaud V. 2007. Purification and characterization of Cassiicollin toxin produced by Corynespora cassiicola causal agent of the leaf fall disease of rubber tree. J Chrom 849: 357-362.

Déon M, Bourré Y, Gimenez S, Berger A, Bieysse D, de Lamotte F, Poncet J, Roussel V, Bonnot F, Oliver G. 2012a. Characterization of a cassiicolin-encoding gene from Corynespora cassiicola, pathogen of rubber tree (Hevea brasiliensis). Plant Sci 185-186: 227-237. DOI: 10.1016/j.plantsci.2011.10.017

Déon M, Scomparin A, Tixier A, Mattos CR, Leroy T, Seguin M, Roeckel-Drevet P, Pujade-Renaud V. 2012b. First characterization of endophytic Corynespora cassiicola isolates with variant cassiicolin genes recovered from rubber trees in Brazil. Fungal Diver 54 (1): $87-$ 99. DOI: $10.1007 / \mathrm{s} 13225-012-0169-6$

Déon M, Fumanal B, Gimenez S, Bieysse D, Oliveira RR, Shuib SS, Breton F, Elumalai S, Vida JB, Seguin M, et al. 2014. Diversity of the cassiicolin gene in Corynespora cassiicola and relation with the pathogenicity in Hevea brasiliensis. Fungal Biol 118 (1): 32-47. DOI: 10.1016/j.funbio.2013.10.011

Dixon LJ, Schlub RL, Pernezny K, Datnoff LE. 2009. Host specialization and phylogenetic diversity of Corynespora cassiicola. Phytopathology 99 (9): 1015-1027. DOI: 10.1094/PHYTO-99-9-1015

Drummond AJ, Ashton B, Buxton S, Cheung M, Cooper A, Duran C, Field M, Heled J, Kearse M, Markowitz S. 2012. Geneious v5.6. Biomatters, New Zealand.

Farr D, Rossman A. 2019. Fungal Databases. Systematic Mycology and Microbiology Laboratory, U.S. National Fungus Collections, ARS, USDA. https: //nt.ars-grin.gov/fungaldatabases/.

Fernando THPS, Jayasinghe CK, Wijesundera RLC, Silva WPK, Nishantha EADN. 2010. Evaluation of screening methods against Corynespora leaf fall disease of rubber (Hevea brasiliensis). J Plant Diseases Protec 117 (1): 24-29. DOI: 10.2307/43229087.

Friesen TL, Faris JD, Solomon PS, Oliver, RP. 2008. Host-specific toxins: effectors of necrotrophic pathogenicity. Celular Microbiol 10 (7): 1421-1428. DOI: 10.1111/j.1462-5822.2008.01153.x

Hall TA. 1999. BioEdit: A User-Friendly Biological Sequence Alignment Editor and Analysis Program for Windows 95/98/NT. Nucleic Acids Symp 41: 95-98

Liu XB, Li BX, Chen S, Huang GX. 2016. Diversity and pathogenicity of the cassiicolin gene in Corynespora cassiicola of rubber tree in China. Chinese J Tropic Crops 37: 1969-1973.

Lopez D, Ribeiro S, Label P, Fumanal B, Venisse J-S, Kohler A, de Oliveira RR, Labutti K, Lipzen A, Lail K, Bauer D, Ohm RA, Barry KW, Spatafora J, Grigoriev IV, Martin FM and Pujade-Renaud V. 2018. Genome-Wide Analysis of Corynespora cassiicola Leaf Fall Disease Putative Effectors. Front Microbiol 9: 276. DOI: 10.3389/fmicb.2018.00276

Nghia N, Kadir J, Sunderasan E, Abdullah M, Malik A, Napis S. 2008. Morphological and inter Simple Sequence Repeat (ISSR) Markers Analyses of Corynespora cassiicola Isolates from Rubber Plantations in Malaysia. Mycopathologia 166: 189-201.

Ogbebor ON. 2010. The status of three common leaf diseases of Para rubber in Nigeria. J Anim Plant Sci 6 (1): 567-570.

Oktavia F, Kuswanhadi, Widodo, Dinarty D, Sudarsono. 2017. Pathogenicity and rDNA-ITS sequence analysis of the Corynespora cassiicola isolates from rubber plantations in Indonesia. Emirates J Food Agricul 29 (11): 872-883. DOI: 10.9755/ejfa.2017.v29.i11.1497.

Othman R 2013. Development of high yielding disease resistance clones. IRRDB Agronomy Workshop Medan, Indonesia.

Petrov V, Qureshi MK, Hille J, Gechev T. 2018. Occurrence, biochemistry and biological effects of host-selective plant mycotoxins. Food Chem Toxic 112: 251-264. doi.org/10.1016/j.fct.2017.12.047 
Pujade-Renaud V, Lopez D, Ribeiro S, Minh T, Deon M, ClementDemange A, Garcia D, Drevet P, Label P, Morin E. 2015. The effectors of Corynespora cassiicola virulence in rubber tree International Rubber Conference 2015, Ho Chi Minh, Vietnam, Agriculture Publishing House, Vietnam.

Rampersad SN, Perez-Brito D, Torres-Calzada C, Tapia-Tussell R, Carrington CV. 2013. Genetic structure and demographic history of Colletotrichum gloeosporioides sensu lato and C. truncatum isolates from Trinidad and Mexico. BMC Evol Biol 13 (1): 1-17. DOI: 10.1186/1471-2148-13-130

Ribeiro S, Tran DM, Deon M, Clément-Demange A, Garcia D, Soumahoro M, Masson A, Pujade-Renaud V. 2019. Gene deletion of Corynespora cassiicola cassiicolin Cas1 suppresses virulence in the rubber tree. Fungal Genet Biol 129: 101-114. DOI 10.1016/j.fgb.2019.05.004

Shuib SH, Deon M, Mahyuddin MM, Izhar A, Fumanal B, Sunderasan E, Pujade-Renaud V. 2015. Cassiicolin genes among Corynespora cassiicola isolates from rubber plantations in Malaysia. J Rubber Res 18 (2): 6241-6246

Tran DM, Clément-Demange A, Deon M, Garcia D, Le Guen V, Cle'ment-Vidal A, et al. 2016. Genetic determinism of sensitivity to Corynespora cassiicola exudates in rubber tree (Hevea brasiliensis). PLoS ONE 11 (10): e0162807. DOI: 10.1371/journal.pone.0162807.

Wu J, Xie X, Shi Y, Chai A, Wang Q, li B. 2018. Variation of cassiicolin genes among Chinese isolates of Corynespora cassiicola. J Microbiol 56: 634-647. DOI: 10.1007/s12275-018-7497-5

Xianbao L, Boxun L, Shan C, Guixiu H. 2016. Diversity and Pathogenicity of the Cassiicolin Gene in Corynespora cassiicola of Rubber Tree in China. J Tropical Crops 10: 1969-1973

Xianbao L, Tao S, Yanli F. 2019. Analysis of host specificity and pathogenicity of Cas5 isoform cassiicolin in Corynespora cassiicola from Hevea brasiliensis. [abstract]. Proceedings of the 2019 Annual Meeting of the Chinese Academy of Plant Pathology. 